\title{
Factors affecting antibacterial activity of acrylic resin containing silver nanoparticles
}

\author{
Phan Quoc Phu, Nguyen Vo Dang Canh, Pham Thi Le, Tran Pham Thi To Quyen, La \\ Thi Thai Ha \\ Ho Chi Minh city University of Technology - Vietnam National University - Ho Chi Minh City
}

(Received 18 October 2016, accepted 23 November 2016)

\begin{abstract}
In this research, silver nanoparticles were dispersed into acrylic emulsion by high-speed stirring method using scattered disc at room temperature. Antibacterial activity of the mixture was examined through changes of some parameters such as nanosilver concentration, dispersing time and water addition amount. The antibacterial properties were evaluated via changes of number and size of colonies forming on the surface of the film casting from this
\end{abstract}

Key word: silver nanoparticles; acrylic liquid resins; antibacterial.

\section{INTRODUCTION}

Nowadays, the effects of environmental pollution and climate change on the risk of disease have increased such as: cholera, tuberculosis and plague [1]. In particular, there are many new species of bacteria causing a lot of infectious disease outbreaks such as SARS, A/H5N1, and A/H1N1. Therefore, the demands of protection and healthcare for human have been concentrated. Besides of focusing on researches of super bacteria resistant and antifungal medicines, researchers have studied to manufacture products containing nanoscale materials for killing off pathogens [2].

In recent years, there are a lot of researches demonstrated that when size of silver particles mixture in petri dishes. Besides that, the silver nanoparticles distribution ability into the film was evaluated through the analysis of scanning electron microscope images. As results, the surfaces of the acrylic resin shown on the high antibacterial resistance rates reached about $97.89 \%$ for 1,500 ppm silver nanoparticles dispersing into acrylic emulsion in 3 hours with the water addition amounts about 5\%. decreases to nanoscale with high surface area will show the antibacterial activity without affecting to humans and the environment [3-4]. Therefore, the products containing silver nanoparticles have been studying for application in the world. In addition, the research of antibacterial polymer have also achieved a lot of particular success such as poly (acrylic acid) [56] using in common.

In general, this research objectiveis to combine the antimicrobial activity of the silver nanoparticles and acrylic resin were prepared by mixing them using scattered disc. Effects of some factors such as silver nanoparticle concentration, dispersion time as well as dilution water level were used to inhibit 
bacterial growth or kill bacterial pathogens of the film surface.

\section{EXPERIMENTAL}

\subsection{Materials}

Silver colloid nanoparticles (AEM5700AD, 26\%, China), acrylic emulsion (DS-910, 50\%, Vietnam), Nutrient Agar (M001-500G, India) and distilled water were used for all experiments.

\subsection{Methods}

To reduce the possibility of infections spreading between colonies in the laboratory, the instruments were sterilized before carrying out the experiment.

Firstly, $100 \mathrm{~g}$ of acrylic emulsion with high viscosity $(10,400 \mathrm{cP})$ was diluted with distilled water at different contents changed from $5 \%$ to $15 \%$ in becher $250 \mathrm{ml}$ for 30 minutes to get the appropriate viscosity for dispersion and film casting processes.

Then, three amounts of the silver colloid nanoparticles were formulated to contain 500 ppm, 1,000 ppm and 1,500 ppm. The dispersion of the nanoparticles in the acrylic emulsion was made by the impact of scattered disc at a speed about $750 \mathrm{rpm}$.

The dispersion process was finished after about 1 hour, 2 hours or 3 hours. After dispersion, the mixture of acrylic resin and silver nanoparticles were poured on and poured off the petri dish to form the film, and then the petri dishes with acrylic film were dried for 1 hour at $70{ }^{\circ} \mathrm{C}$ temperature for drying and 2 hours at $150{ }^{\circ} \mathrm{C}$ temperature for sterilizing, respectively.

\subsection{Analysis}

\subsubsection{The plate count method}

The bacteria will be implanted on the surface of the acrylic film and provided nutrition by Nutrient agar in petri dishes. Then the petri dishes are stored in shelter clean places for 24 hours before counting.

The number of colony forming units will be determined by eyes and compared with blank sample without usingthe acrylic film which is prepared in each study (Figure 1).. The antibacterial resistance rates is calculated with the formula $\alpha=\mathrm{N} / \mathrm{N}_{\mathrm{o}}$

Beside that, the size of the colonies will be determined by Ultimate Paint software. The formula for calculating the size of the colonies on writing is $\mathrm{D}_{\mathrm{c}}=\mathrm{D}_{\mathrm{p}} * \mathrm{D}_{\mathrm{c}}, / \mathrm{D}_{\mathrm{p}}$,

Where $\mathrm{N}_{\mathrm{o}}$ is the number of the colonies forming on the blank sample, $\mathrm{N}$ is the number of the colonies forming on the acrylic film surface, $D_{p}(m m)$ is the diameter of the petri dishes, $D_{p}$, (pixel) is the pixel diameter of the petri dishes, and $\mathrm{D}_{\mathrm{c}}$, (pixel) is the average pixel diameter of the colonies. 


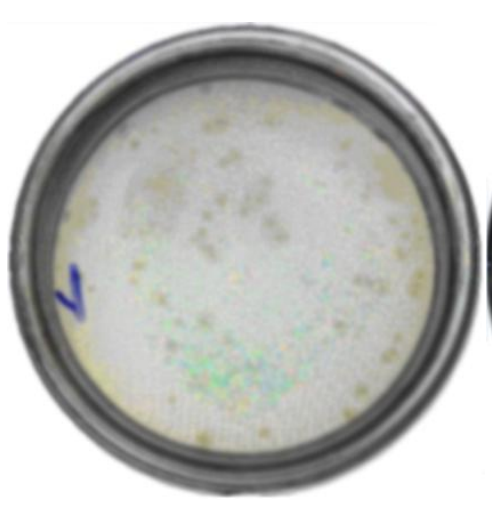

(a)

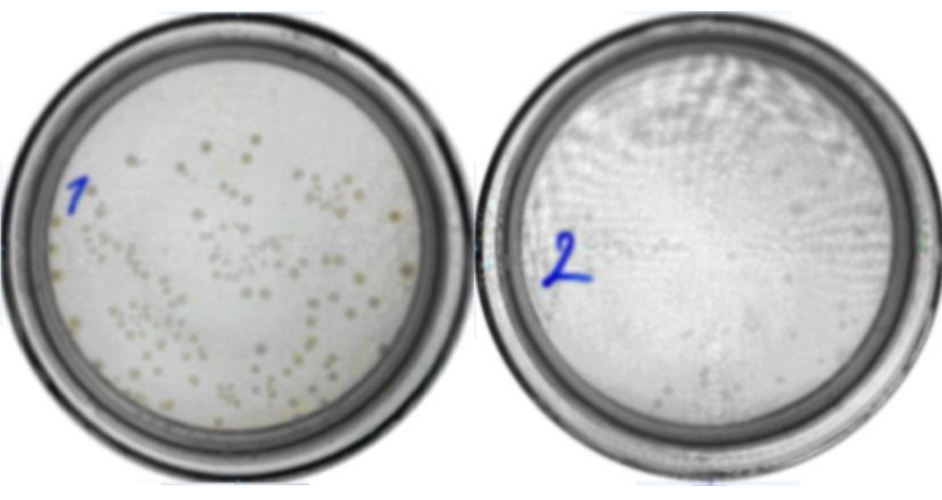

(b)

(c)

Figure 1. Photos of the petri dishes of the blank samples in the different experiments

surveying the effects of silver nanoparticle concentration (a), surveying the effects of dilution water level (b), surveying the effects of dispersion time (c)

\subsubsection{Morphological studies}

Scanning electron microscope (SEM) was used to analyze the silver nanoparticles disperse ability on the surface of the acrylic film when the dispersion time was increased from 1 hour to 3 hours by SEM JSM-6480LV, at Laboratory for Nanotechnology, in Vietnam National University HCM City.

\section{RESULTS AND DISCUSSION}

\subsection{Silver nanoparticle concentration}

After $100 \mathrm{~g}$ acrylic emulsion was diluted with $5 \mathrm{~g}$ water, the silver colloid nanoparticles were dispersed for 1 hour with three different concentration levels (500 ppm, 1,000 ppm and $1,500 \mathrm{ppm})$.

In the figures 2-a, 2-b and 2-c, the color of acrylic film in the petri dishes was turned into yellow because of the sterilizing process at temperature of $150{ }^{\circ} \mathrm{C}$ in 2 hours. Some small spots appeared in the petri dishes showed the number and size of the colony-forming units (Figure 2-a).Through the images in figure 2, the results were presented by the bar charts in the figure 3 .

The chart in the figure 3-a showed that the number of colonies significantly decreased when the silver nanoparticles ascending were dispersed into the acrylic and the samples had the lowest number about 31 colonies with the 1,500 ppm silver nanoparticles specimens. Besides that, the size of the colonies also reduced from $2.185 \mathrm{~mm}$ to $1.368 \mathrm{~mm}, 0.998$ $\mathrm{mm}$, and $0.875 \mathrm{~mm}$ in the samples with 500 ppm, 1,000 ppm and 1,500 ppm of nanoparticles samples compared with the blank sample, respectively (Figure 3-b). 


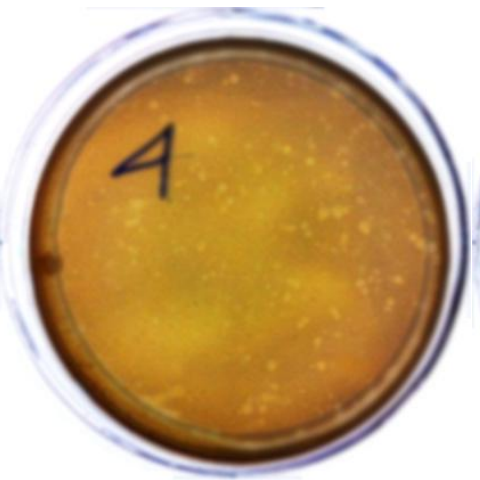

(a)

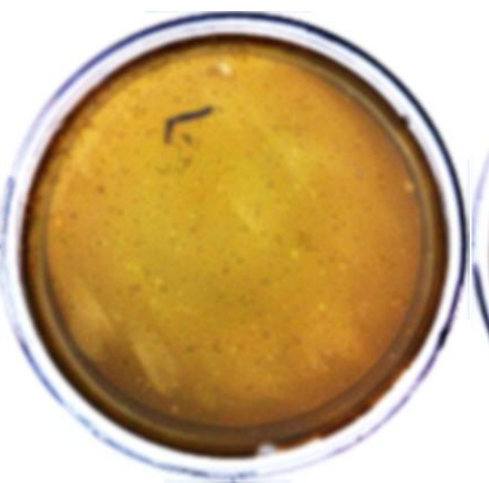

(b)

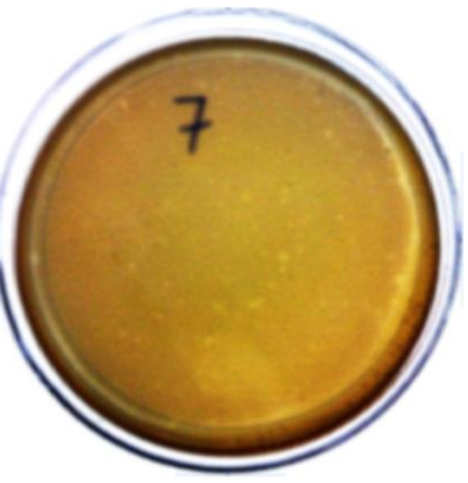

(c)

Figure 2. Photos of the petri dishes of the samples with the different silver nanoparticle concentration: 500 ppm (a); 1,000 ppm (b), 1,500 ppm (c)

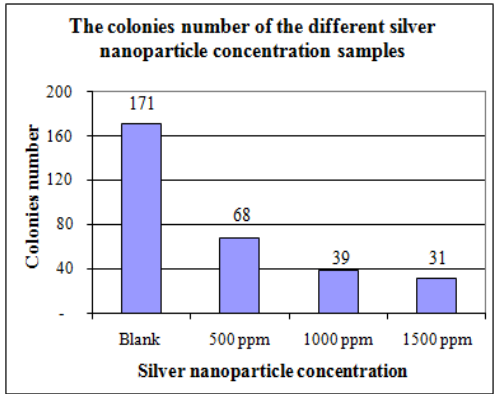

(a)

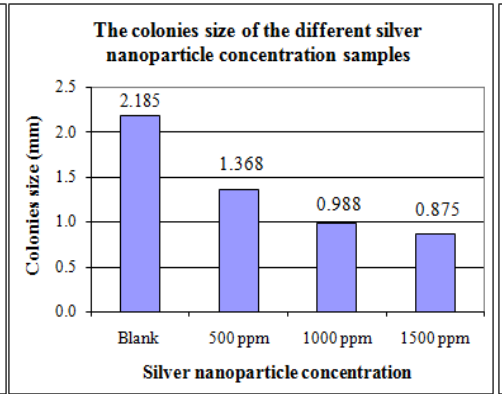

(b)

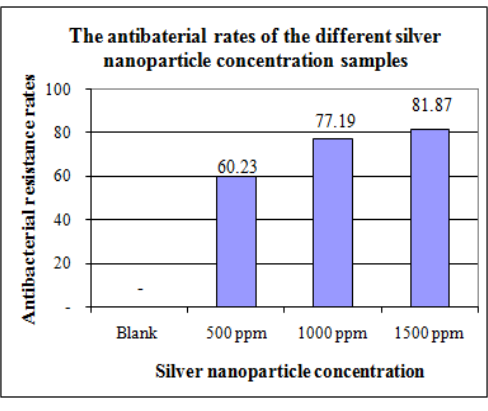

(c)

Figure 3. The bar charts display the colonies number (a), the colonies size (b) and the antibacterial resistance rates (c) of samples with the different silver nanoparticle concentration

The results showed that the high concentrations of the silver nanoparticles lead to enhance the ability to interact and destroy cells for decreasing the number of bacteria. However, some of varieties and types of bacterial were incompletely destroyed but restrained from proliferating.

Therefore, the antibacterial activities of the acrylic film were not changed much even when the concentrations of the silver nanoparticles were increased from 1,000 ppm to $1,500 \mathrm{ppm}$.

\subsection{Dilution water level}

The acrylic mixtures using for the experiment were prepared by the stirring dispersion process of $1,500 \mathrm{ppm}$ silver nanoparticles in $100 \mathrm{~g}$ acrylic emulsion during 3 hours. The water amounts used to dilute the mixture were changed from $5 \mathrm{~g}$ to $15 \mathrm{~g}$. The measurement results were shown in the photos of the petri dishes of three samples in figure 4 .

The results in the figure 5 showed that the mixtures were diluted with the changes of water amount gave the same of the colony-forming units on the acrylic film surface for about 20 colonies. However, the colonies size increased from $0.917 \mathrm{~mm}$ to $1.305 \mathrm{~mm}$ when the amount of water increased from $5 \%$ to $15 \%$ showing the different progress rates. The ascending of the colonies size showed the changes of nano-silver concentrations on the surface of the acrylic film when the amount of water were adjusted.

Due to the using of more water, the mixtures were more diluted and the film

\section{Trang 20}


forming time was longer. As a result, dilution mixtures created the conditions for the large size of nano-silver settled into the plastic film and reduced the concentration of the

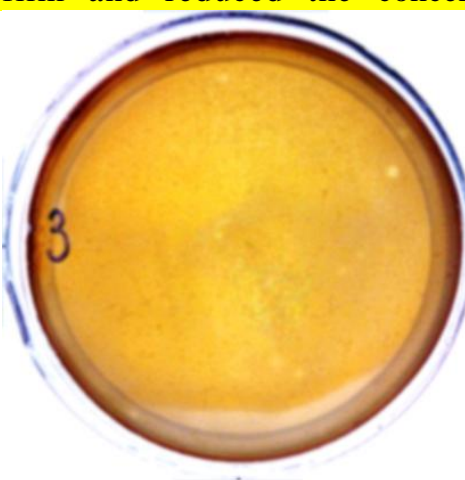

(a)

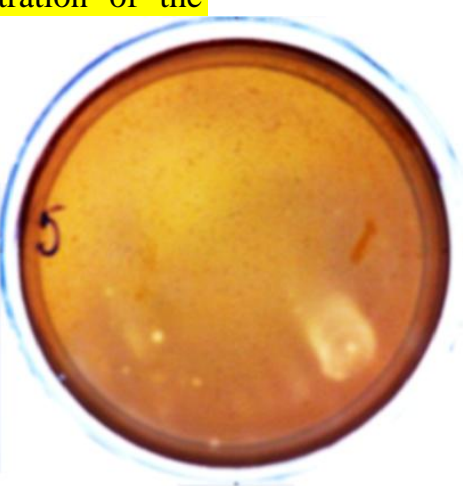

(b)

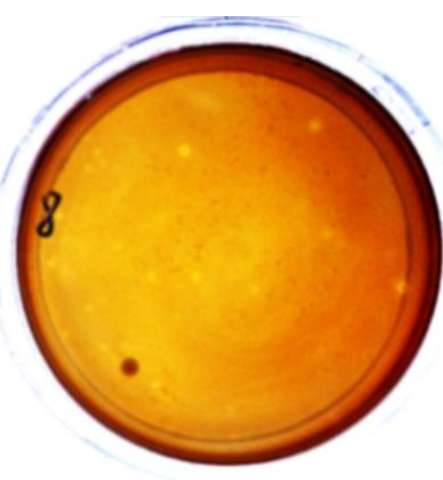

(c)

Figure 4. Photos of the petri dishes of the samples with the different dilution water level: $5 \%$ (a); $10 \%$ (b), $15 \%$ (c)

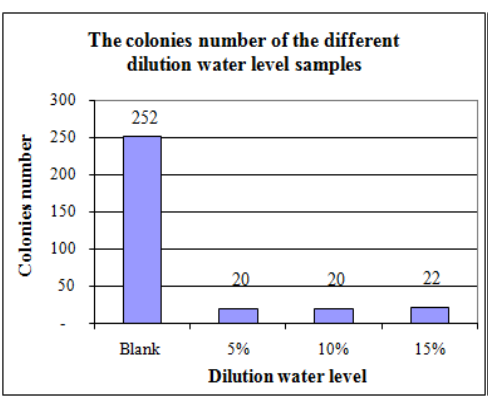

(a)

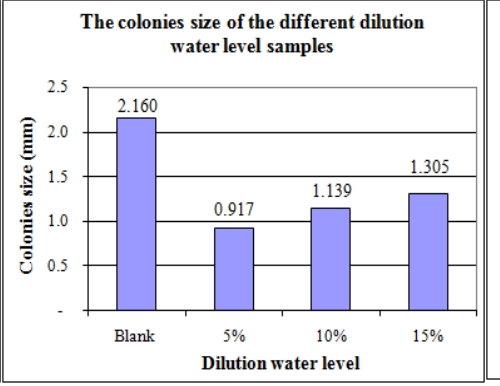

(b)

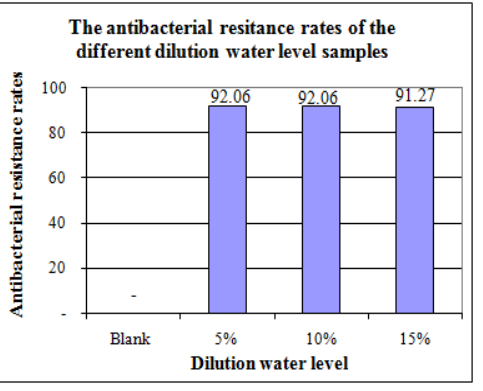

(c)

Figure 5. The bars charts display the colonies number (a), the colonies size (b) and the antibacterial resistance rates (c) of samples with the different dilution water level

\subsection{Dispersion time}

In this experiment, the concentration of $1,500 \mathrm{ppm}$ nano-silver was used to disperse in $100 \mathrm{~g}$ acrylic emulsion with $5 \mathrm{~g}$ water. The mixture was dispersed in 1 hour, 2 hours and 3 hours. As can be seen in the figure 6 and the figure 7 , the results showed that the antibacterial resistance rates increased from $82.11 \%$ to $93.68 \%$ when the dispersion time increased from 1 hour to 2 hours (Figure 7-c). In particular, the rates got the highest values at $97.89 \%$ for the sample dispersion at 3 hours.
The reduction of the colonies number from 17 to 6 showed the high affect of the dispersion time of the silver nanoparticles in the acrylic film.

To verify the statements about the silver nanoparticles dispersion ability into the acrylic film by changing stirring time, the samples of 1 hour and 3 hours dispersion were taken SEM and the results were presented at the figure 8 . The scanning electron microscope images of the two samples taken at magnification of $\times 200$ appeared a lot of white agglomerates on the film surface called the continuous precipitation of the 
silver nanoparticles which were needed more stirring time to separate into smaller agglomerates or even individual nanoparticle.

With the samples made from the mixture stirred in the short dispersion time, the agglomerates could not be completely broken into the individual particular. The figure 8 -a showed the dispersion of the nanoparticles on the film surface was not good and had the multiple placements without the nano-silver creating condition for the duplication of the bacteria. Whereas, the samples with 3 hours dispersion showed that the agglomerates were separated and distributed more evenly on the surface of the acrylic film (Figure 8-b).

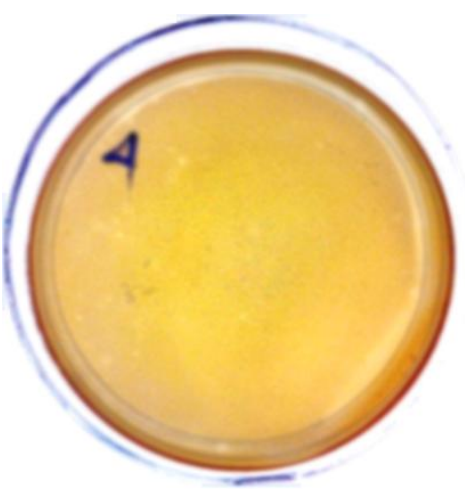

(a)

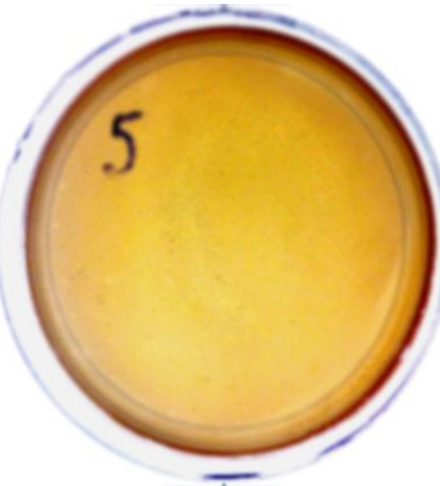

(b)

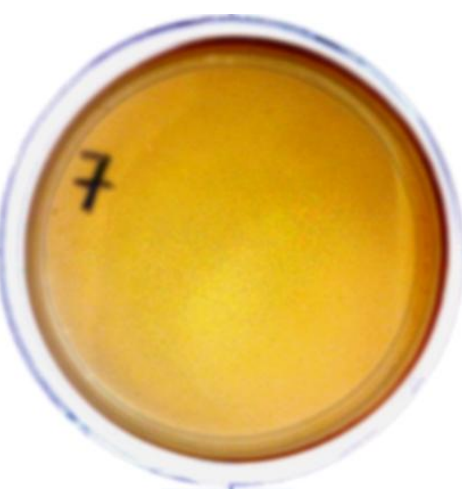

(c)

Figure 6. Photos of the petri dishes of the samples with the different dispersion time: 1 hour (a), 2 hours (b), 3 hours (c)

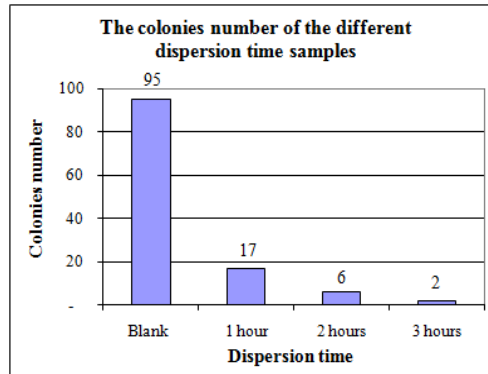

(a)

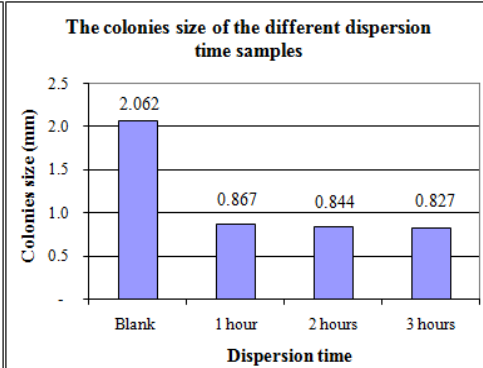

(b)

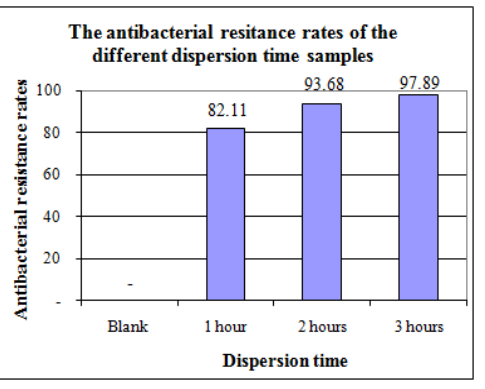

(c)

Figure 7. The bars charts display the colonies number (a), the colonies size (b) and the antibacterial resistance rates (c) of samples with the different dispersion time 


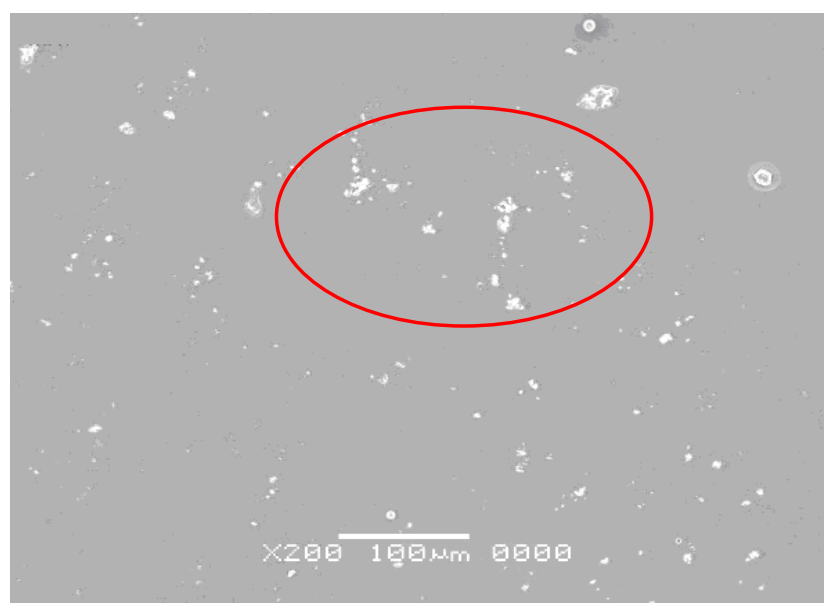

(a)

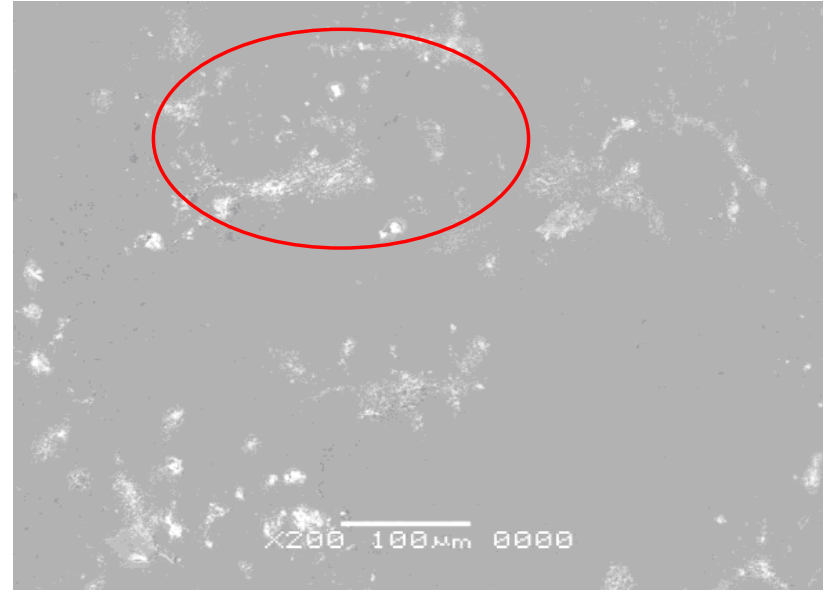

(b)

Figure 8. SEM images of the top surface of the acrylic film samples with different dispersion time:

1 hour (a), 3 hours (b) taken at a magnification of $x 200$

\section{CONCLUSIONS}

The results showed the successful in the dispersing the silver nanoparticles into the acrylic resin by the high-speed stirring method. The experimental had also demonstrated the antibacterial activity of the acrylic resin containing the silver nanoparticles. The film with the range of 1,000 to $1,500 \mathrm{ppm}$ silver nanoparticles concentrations dispersing into the acrylic showed the antibacterial resistance rates roughly $80 \%$.

In addition, the dilution amount and the dispersion time were also affected on the dispersion silver nanoparticles ability with the changes of the antibacterial activity of the acrylic film. The film made from the mixture of 3 hours dispersion with 5\% water addition and $1,500 \mathrm{ppm}$ silver nanoparticles shown the uniform distribution in the surface with the antibacterial rate achieved $97.89 \%$ and the size of the colonies were $0.827 \mathrm{~mm}$.

Based on this research, there are applications of the acrylic resin containing the silver nanoparticles with the antibacterial activity remain open and should be studied further, such as water heaters, water filtration, household products, and so on. 


\section{Các yếu tố ảnh hưởng đến khả năng kháng khuẩn của nhựa acrylic có chứa các hạt nano bạc}

Phan Quốc Phú, Nguyễn Võ Đăng Cảnh, Phạm Thị Lệ, Trần Phạm Thị Tố Quyên, La Thị Thái Hà

Trường Đại học Bách khoa, Đại học Quốc gia thành phố Hồ Chí Minh

\section{TÓM TĂT}

Trong nghiên cứu này, hạt nano bạc sẽ dược cho vào trong dung dịch nhựa acrylic bằng phuơng pháp khuấy đĩa phân tán tại điều kiện nhiệt độ phòng. Khả năng kháng khuẩn của hạt nano bạc có trong nhựa acrylic sẽ được khảo sát thông qua việc thay đổi các thông số nhu: hàm lượng nano bac, thờ gian phân tán và hàm lượng nước pha loãng. Khả năng kháng khuẩn của hỗn hợp nhựa được đánh giá thông qua số luợng lac thể tạo thành và sụ phân bố của hạt nano bac được đánh giá thông qua ảnh SEM. Kết quả cho thấy màng phủ tạo thành cho tỷ lệ kháng khuẩn đạt cao nhất là 97,89\% có hàm lương nano bac là 1.500 ppm, hàm luợng nuớc dùng để pha loãng hỗn hợp khoảng $5 \%$ và phân tán trong thời gian 3 giò.

Tù khóa: silver nanoparticles; acrylic liquid resins; antibacterial.

\section{REFERENCES}

[1]. Christian Witt, André Jean Schubert, Melissa Jehn, Alfred Holzgreve, Uta Liebers, Wilfried Endlicher, Dieter Scherer, The Effects of Climate Change on Patients With Chronic Lung Disease, Dtsch Arztebl Int, Vol. 112, No. 51, pp 878-883, (2015).

[2]. Mohammad J. Hajipour, Katharina M. Fromm, Ali Akbar Ashkarran, Dorleta Jimenez de Aberasturi, Wolfgang J. Parak and Morteza Mahmoudi, Antibacterial properties of Nanoparticles, Biotechnology, Vol. 30, No. 10, pp 499511, (2012).

[3]. Benjamin Le Ouay, Francesco Stellacci, Antibacterial activity of silver nanoparticles: A surface science insight, Nano Today, Vol.10, pp. 339-354, (2015).

[4]. Nelson Durán, Marcela Durán, Marcelo Bispo de Jesus, Amedea B. Seabra, Wagner J. Fávaro, Gerson Nakazato, Silver nanoparticles: A new view on mechanistic aspects on antimicrobial activity, Nanotechnology, Biology and Medicine, Vol. 12, No. 3, pp 789-799, (2016).

[5]. Alexandra Pica, Cornelia Guran, Denisa Ficai, Anton Ficai, Florica Dumitru, Acrylic polymer influence on the structure and morphology of AgNPs obtained by chemical method for antimicrobial applications, Coatings Technology and Research, Vol. 13, No. 1, pp 53-61, (2016).

[6]. Alaa Fahmy, Wael H. Eisa, Mohamed Yosef, and Ali Hassan, Ultra-Thin Films of Poly(acrylic acid)/Silver Nanocomposite Coatings for Antimicrobial Applications, Journal of Spectroscopy, Vol. 2016, No. 5, pp 1-11, (2016). 